\title{
Organizational Factors Contributing to Job Satisfaction and Burnout among Social Workers and What to Do About It
}

Siri Jayaratne \& Reem S. Ibrahimi School of Social Work, University of Michigan 


\section{Egyptian Journal of Social Work (EJSW) http://ejsw.journals.ekb.eg \\ Print ISSN: 2356-9204 Online ISSN: 2356-9212 Vol 1, Issue 1, June 2015}

\section{Abstract}

Job satisfaction and burnout are two concepts that have received considerable attention in human services literature in the U.S. Dissatisfaction with one's job has been associated with a variety of negative mental health and health consequences such as depression and anxiety to the development of physical symptoms. As a symptom, burnout has been typically thought of as a response to chronic stress, and has also been associated with a host of negative health and mental health symptoms. While job satisfaction and burnout may be related phenomena, they are generally not viewed in the literature as being progressive or stepwise - that is, lack of satisfaction does not necessarily precede burnout nor does satisfaction with the job prevent burnout. Both, however, could result in poor service to clients, cost to employers because of absenteeism and turnover, and in the long run, negative impact on the worker (Halbesleben \& Buckley, 2004; Shirom, 2003).

We will not go in to the theories and meta-theories associated with these two concepts. Instead, we will simply state our definitions, which by and large reflect the definitions in the majority of the literature.

Keywords: Organizational Factors- Job Satisfaction-

\section{Introduction}

Job satisfaction is viewed as an "affective state" resulting from interactions and transaction with the work environment (Caplan et al., 1975).

Burnout is viewed as a psychological strain resulting in emotional exhaustion, depersonalization and lower personal accomplishment resulting from chronic interactions and transaction with the environment (Dentsen, 2002; Freudenberger, 1980; Maslach, 1982, 2003.

Thus, both definitions are viewed as dimensions that need to be explored within the classic "person-in-environment" approach. However, while notions of person-environment or job-person-fit introduce a general framework for analysis, burnout is considered more an "end state," something that may be the result of "chronic misfit" (Maslach et al., 2001).

There is considerable evidence to support the view that organizational factors are perhaps the most significant predictors of 
job satisfaction burnout, with workers in large bureaucracies appearing to be the most susceptible (Maslach et al., 2001, 2003). This research generally points to the important role played by the culture, climate, and structure of the organization. While personal characteristics (e.g., sex, age) and the very nature of the work (e.g., cancer patients, domestic violence) may indeed contribute to job satisfaction and burnout, the vast majority of evidence suggests that organizational factors are the most critical to examine in this regard.

There is also considerable evidence that a supportive workplace environment will help reduce or "buffer" against the negative consequences of stress. That is, the presence of social support in its different forms (emotional, instrumental, informational, and appraisal) from coworkers and supervisors may help individuals to better cope with stress at work (Acker, 1999; Barak et al., 2001; Baruch-Feldman \& Schwartz, 2002; Gant et al, 1993; Greenglass, et al., 1996; Hagihara, et al., 1998; Himle et al., 1989a; Himle et al., 1989 b; Jayaratne et al., 1984). In contrast, there is also evidence that social undermining, behaviors and actions that degrade the person and or the work they do, may heighten the process of job dissatisfaction and burnout (Duffy, 2002; Gant et al., 1993; Singh et al., 1991, 1995; Tepper et al., 2001).

Figure 1 identifies some of the more widely accepted dimensions central to job satisfaction and burnout. The model indicates that there are direct effects on job satisfaction and burnout from the person (characteristics of the worker), organization (characteristics of the organization), and client (nature of the work). This model also notes that social support and undermining falls between the domains and job satisfaction and burnout, suggesting the idea of buffering or exacerbation. We have also included "family" as an important factor that needs to be examined in this type of analysis. For example, a husband may be supportive of the work being done by his wife and support her when she talks about the stressors at work. On the other hand, he may be non-supportive and encourage her to leave the job. Thus, "what happens at home" may have a significant impact on the worker's ability to be an effective worker and could contribute to dissatisfaction with the job and feelings of burnout (see, for example, Frone, 2003; Frye \& Breaugh, 2004). And, of course, what happens at work may have a negative impact on the family as 
Egyptian Journal of Social Work (EJSW) http://ejsw.journals.ekb.eg

Print ISSN: 2356-9204 Online ISSN: 2356-9212 Vol 1, Issue 1, June 2015

well.

Figure 1: Conceptual model on the situational correlates of job satisfaction and burnout

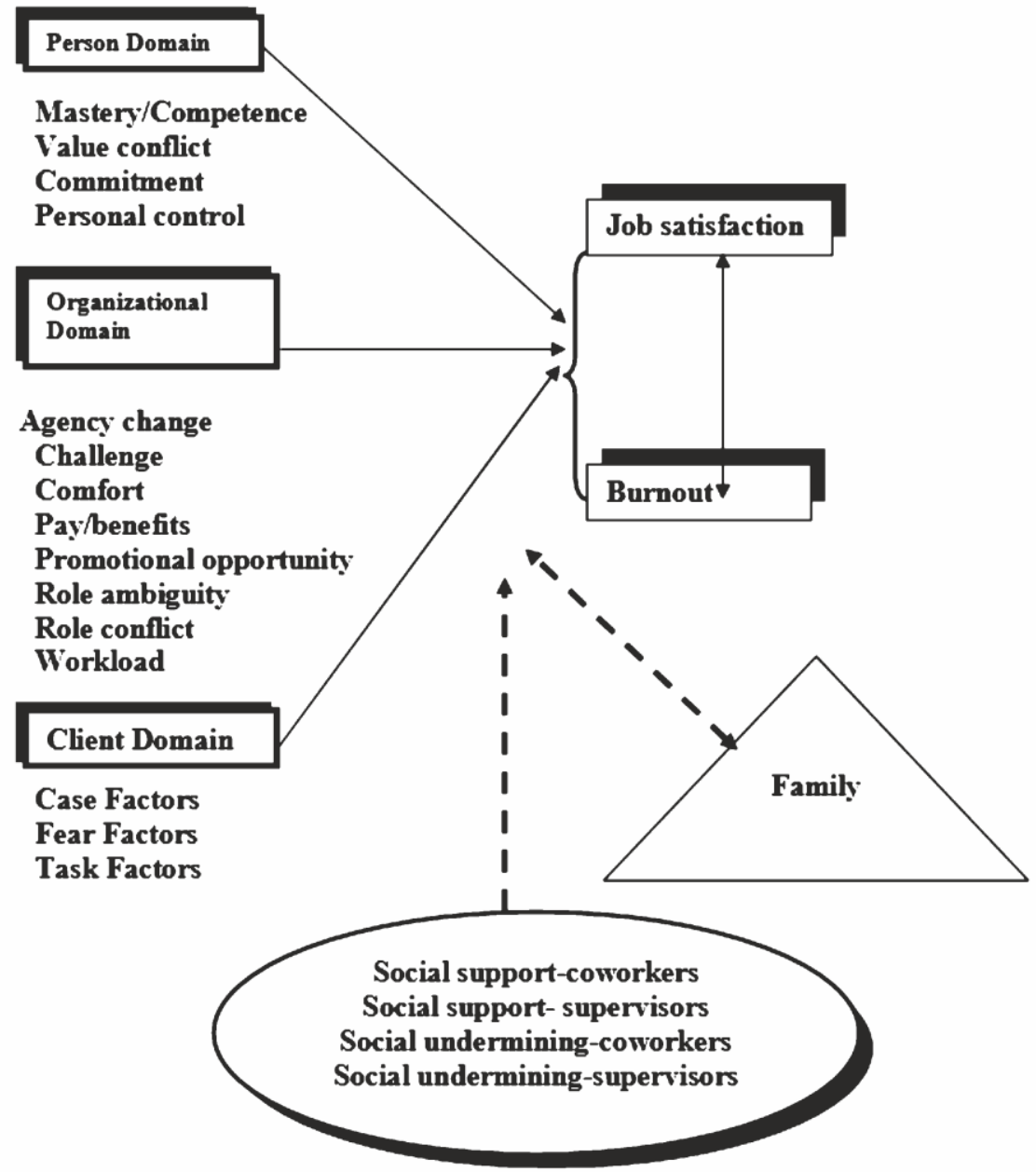


Egyptian Journal of Social Work (EJSW) $\underline{\text { http://ejsw.journals.ekb.eg }}$

Print ISSN: 2356-9204 Online ISSN: 2356-9212 Vol 1, Issue 1, June 2015

Table 1: Definitions of situational correlates

\section{PERSONAL DOMAIN}

Mastery/Competence

Value Conflict

Commitment

Personal Control

\section{Organizational Domain}

Agency change

Challenge

Comfort

Pay/benefits

Promotional Opportunity

Role Ambiguity

Role Conflict
The extent to which individuals believe they possess the necessary training and skills to perform their job.

The extent to which individuals feel their personal values are in conflict with what is required in the job.

The extent to which individuals believe in the "goodness" of the work, and an attachment to the organization.

The extent to which individuals believe that there are sufficient resources and authority to conduct their work in the most efficacious and autonomous manner.

The extent to which changes in agency policies and procedures are seen as problematic by the individual

The extent to which an individual sees a job as stimulating and offers opportunity for creativity and growth

The extent to which an individual sees the workplace as a comfortable physical environment.

The degree of satisfaction with the compensation and benefits received by individuals for what they do.

The extent to which an individual believes there is a career ladder and fair opportunities for promotion

The extent to which an individual perceives an absence of clarity about the nature of the job.

The extent which an individual experiences conflicting demands from different parts of the organization, and 
Egyptian Journal of Social Work (EJSW) http://ejsw.journals.ekb.eg

Print ISSN: 2356-9204 Online ISSN: 2356-9212 Vol 1, Issue 1, June 2015

Workload

frustrations encountered by fulfilling one goal while contradicting another.

The extent to which an individual feels there is an excessive quantity of work that is expected on the job.

\section{Client Domain}

Case Factors

Fear Factors

Task Factors

$\underline{\text { Social Support }}$

Social Understanding
The extent of difficulties inherent to a client and his/her context that an individual perceives to be present in the provision of services

The extent to which an individual believes there is personal danger in the conduct of work activities.

The extent to which an individual feels confident in carrying out the activities necessary in a given situation.

The extent to which the individual perceives a supportive environment at work and outside work

The extent to which individuals in the workplace are viewed as actively demonstrating negative and demoralizing behaviors

Table 1 presents the definitions of the various elements included in our model. This is a fairly comprehensive model that is supported by research conducted around the world with numerous human service workers (e.g., Adams et al., 2006; Cropanzano et al., 2003; Ellett et al., 2007; Guterman \& Jayaratne, 1994; Huxley et al., 2005; Lee \& Ashforth, 1996; Maslach, et al 2001; Mor Barak et al, 2006; Ringstad, 2005; Song, K., 2006; van Dyk, 2007; Zapf et al., 2001).

Methodology

The research presented here represents findings from four different mail surveys conducted with social workers in the U.S. The surveys were conducted between 1986-1996. In each instance, the respondents were selected from the membership of the National Association of Social Workers which has a membership of about 120,000. All surveys used stratified random sampling procedures to 
ensure the inclusion of identified target groups such as racial minorities, private practitioners, and child welfare workers, depending on the particular study. Each survey netted over 750 respondents, and the response rates varied from a high of $72 \%$ to a low of $48 \%$.

What is presented here is composite data reflecting findings from the four different studies. We are emphasizing patterns that came out of the studies rather than discrete bits of information from any one study. As such, they reflect the "preponderance of evidence" across the different studies that held relatively constant with four different cohorts of respondents. Some of these findings may be considered fairly robust because they have been replicated. Other findings are more discrete in that the data are reported only from one or two surveys, but the conclusions are similar to those in the literature. We are not going to talk about the specific statistical procedures we used, but for the most part, we utilized path models, regression, and moderated regression analyses to analyze the data.

Measures

The measures used in this research program have been used in numerous workforce studies. Table 2 presents a summary of the different measures and the original sources and their respective alpha coefficients.

\section{Results}

As we noted earlier, what we intend to present are the most common findings from these different studies. However, in order to contextualize these results, we would like to present a demographic picture of the composite study population. It is probably fair to say that these demographics are representative of the NASW membership.

- Gender - reflects the female character of the social work population in the U.S.; the study population averaged $76 \%$ women.

- Age - the median respondent was 44-years of age, with the ages ranging from twenty one to seventy nine.

- Highest Degree - approximately $86 \%$ of the respondents had M.S.W. degrees and 7\% a Bachelor's Degree.

- Race/ethnicity - a very high proportion of respondents $87 \%$ were white. African American respondents were the second largest racial category with about $5 \%$.

- Marital status - about $62 \%$ of all respondents were married, 
and an additional $18 \%$ separated, divorced or widowed.

- Income - the median income from their social work job ranged between $\$ 25,000-35,000$ before taxes.

- Employment status - nearly $76 \%$ of the respondents indicated they were employed fulltime as social workers and spent 35 -hours or more per week on the job.

- Practice areas - about $26 \%$ of the respondents worked in the mental health area; about $13.4 \%$ worked in health care; and about $13 \%$ in services to children.

Now, let me present some findings, which as I said earlier, are perhaps the results that have received the most amount of support in these four studies. Many of these findings are quite similar to findings from other studies; a few perhaps are unique or distinctive in that not much data are available on these issues.

1. Men respond to stress with anger and irritability, women tend to report anxiety and depression - in other words, there are gender differences in stress responses.

2. Male supervisors are perceived as more supportive than female supervisors by both men and women.

3. The "perception" of support is very important. Individuals may not use the available support, but knowing that it exists is what seems to be important.

4. The presence of social support may help buffer against the negative effects of some stressors, but not all stressors.

5. No matter how much support from workers and supervisors are reported, even a low level of social undermining can lead to serious strains.

6. Married workers overall report lower levels of stress and strain than unmarried workers.

7. Younger workers report more stress and strain compared to older.

8. The best predictors of job satisfaction are challenge, promotional opportunity and workload.

9. The best predictors of burnout are workload, role conflict and agency changes (policy changes).

10. The best predictors of turnover or intention to leave are commitment and promotional opportunity.

Discussion

It should be evident from the results that all three domains - 
person, organization, and client - could contribute to feelings of job satisfaction and burnout. However, it is also clear that organizational factors tend to play a larger role than the other factors. Thus, any attempt to attend to these issues would require a multipronged approach addressing the various dimensions. But, as noted earlier, it is reasonable to expect that some aspects of a work environment that create stress cannot be changed. Because of this, many programs designed prevent burnout tend to be "individual-oriented" stress management (Azar, 2000; Leyden-Rubenstein, 1998; Meltsner, 1989). That is, they focus on the person with the goal of helping them cope better with the stressors. Obviously, this does nothing to change the environment which causes the stress. Some amount of stress is inevitable, but it does not have to cause psychological harm to the individual. Therefore, prevention is not only the responsibility of the worker but also the organization.

Broadly speaking, stress is usually caused by two broad conditions: "the occurrence of discrete events and the presence of relatively continuous problems" (Pearlin et al., 1981). However, as Ellet et. al (2007) notes, "the agency has little control over the nature of the clients served, and even less control over the external environment in which the agency is embedded" (p.275). Therefore, we believe that any interventions designed to reduce stress must not only help the worker cope, but must also focus on organizational structure, usually a more difficult task. As With this dual thrust in mind, we have identified several different strategies based on research by several authors, and together, constitute a viable approach to the problem (Bell et al., 2003; Leiter \& Maslach, 2000; Maslach, 1982; Pearlin \& Schooler, 1978; Skovholt, 2001).

\section{Personal Strategies}

There are many self-help books in the popular press on stress management providing guidelines for everything from good eating and exercise, to Yoga, meditation, or kick boxing. There is nothing wrong with any of these programs, but you have to find the one that works for you.

Identifying the symptoms - a number of psychological, behavioral, and physical symptoms are associated with burnout, and each of us may have a different set of symptoms. What matters is one's subjective experience (Azar, 2000). The more consistently you 
Egyptian Journal of Social Work (EJSW) http://ejsw.journals.ekb.eg

Print ISSN: 2356-9204 Online ISSN: 2356-9212 Vol 1, Issue 1, June 2015

experience the symptoms, the more important it is to do something about it. Put check marks next to the symptoms you are experiencing on the Symptom Checklist (Table 3) for two to three weeks. If the page is filling up, it is time to do something about it.

\section{Table 2: Study measures and primary sources}

\section{PERSONAL DOMAIN}

Mastery/Competence $(\alpha=.88) \quad$ Pearlin \& Schooler (1978)

Value Conflict

Commitment

Personal Control $(\alpha=.78)$

Gutterman \& Jayaratne (1994); Quinn \& Staines (1978)

\section{ORGANIZATIONAL}

\section{DOMAIN}

Agency change $(\alpha=.76)$

Challenge $(\alpha=.73)$

Jayaratne \& Chess (1991)

Caplan et. al. (1975); Quinn \& Sheppard (1974); Quinn \& Staines (1978)

Comfort $(\alpha=.67)$

Pay/benefits $(\alpha=.48)$

Caplan et. al. (1975); Quinn \& Sheppard (1974); Quinn \& Staines (1978)

Promotional Opportunity Caplan et. al. (1975); Quinn \& $(\alpha=.75)$ Sheppard (1974); Quinn \& Staines (1978)

Role Ambiguity ( $\alpha=.64$ )

Quinn \& Staines (1978)

Role Conflict $(\alpha=.71)$

Quinn \& Staines (1978)

Workload $(\alpha=.60)$

Caplan et. al. (1975); Quinn \& Sheppard (1974); Quinn \& Staines (1978)

\section{CLIENT DOMAIN}

Case Factors $(\alpha=.81)$

Jayaratne \& Chess (1991)

Fear Factors $(\alpha=.95)$

Jayaratne \& Chess (1991)

Task Factors $(\alpha=.78)$

Jayaratne \& Chess (1991)

EMOTIONAL SUPPORT $(\alpha$ Caplan et. al. (1975) $=.87)$

SOCIAL UNDERMINING ( $\alpha$ Jayaratne et. al. (1992) $=.75)$ 


\section{Egyptian Journal of Social Work (EJSW) http://ejsw.journals.ekb.eg \\ Print ISSN: 2356-9204 Online ISSN: 2356-9212 Vol 1, Issue 1, June 2015}

JOB SATISFACTION* $\quad$ Quinn \& Sheppard (1974); Quinn \&

Staines (1978)

\section{BURNOUT}

Maslach \& Jackson, (1981)

Depersonalization $(\alpha=77)$

Emotional Exhaustion $(\alpha=$ .89)

Personal Accomplishment $(\alpha$ $=.74)$

* Single item 
Egyptian Journal of Social Work (EJSW) http://ejsw.journals.ekb.eg

Print ISSN: 2356-9204 Online ISSN: 2356-9212 Vol 1, Issue 1, June 2015

Table 3: Daily Symptom Checklist*

$\begin{array}{llllllll}\text { Physical Symptoms } & \underline{\text { Day }} & \underline{\text { Day }} & \underline{\text { Day }} & \underline{\text { Day }} & \underline{\text { Day }} & \underline{\text { Day }} & \underline{\text { Day }} \\ & \underline{1} & \underline{2} & \underline{3} & \underline{4} & \underline{5} & \underline{6} & \underline{7}\end{array}$

Fatigued

and

exhausted

Headaches or other bodily pains

Having trouble

sleeping

Feeling lethargic

\section{Emotional}

\section{Symptoms}

Feeling depressed

A general sense of anxiety

Feeling irritable and quick to anger

Feeling like you are not achieving anything

Thinking about quitting

\section{Behavioral}

\section{Symptoms}

Unwilling to ask for help

Unwilling to accept help

Taking longer than usual to get something done

Wanting to be by yourself

Resisting change

Increased use of 
alcohol

or

medications

\section{Other Symptoms}

Feeling like you are

not doing well in your job

Feel like your coworkers are doing better than you

Criticizing yourself

Second-guessing

your decisions and actions

Feel like you are getting any positive feedback

*Jayaratne, S. (2006)

Coping with stress - now that you know you are experiencing some of the symptoms of stress, what should you do? What are your social resources? Are there individuals you can talk with or rely on when you need help and support? Think not only about family and friends, but also consider institutional resources that the agency might have, or your church or mosque. Be specific. If you had a bad experience or a bad day, go out in the evening with a friend. Simple solutions - but the research tells us they do work. This is the time to use your network of social support before things get worse.

Problem-focused coping -- What can you do to increase your mastery and control over the situation? If you feel there is too much to do and you cannot get it all done, you may begin to worry about your ability to do the job. You may not want to talk with your supervisor or with a co-worker because you are concerned they will think you are not competent. Ask yourself why you are thinking this way about your supervisors and co-workers? Have you had bad experiences with them before or is this what you think will happen? To regain mastery over the situation, it is necessary to get your confidence back. If you really believe you cannot talk with someone at work, find someone outside the of work; if it is a specific problem you are encountering with a client, do some additional reading on the topic; try something 
Egyptian Journal of Social Work (EJSW) http://ejsw.journals.ekb.eg

Print ISSN: 2356-9204 Online ISSN: 2356-9212 Vol 1, Issue 1, June 2015

different and don't let feelings of helplessness take over.

Emotion-focused coping -- If, on the other hand, you are dealing with a situation that cannot be changed, consider what you can do to reduce its impact. You have to do a lot of overtime work, and you are worried about spending time with your family. The one and a half hour commute to work and back is very tiring, but you cannot move. These may be realities over which you have little control. If true, this is where personal well-being programs and planned activities become important. Try not to leave things to chance. Can you stay later than usual at work one day so that you can leave on time the next day? The more control you can take over your life the more effective you are likely to be in your professional work.

Maximize the possibility of success - What does it mean to be successful at work? Getting pay raises and promotions are perhaps solid indicators, but they don't happen every week or every month. It is generally a good idea to look for the "small successes" - completing all of the paper work or hearing your supervisor say something good about you. Just as some little things irritate you, some other little things may make you feel better. If you simply wait for something big such as a raise or a promotion as the only ways of defining success, this may prove to be harmful (Acker, 1999; Raquepaw \& Miller, 1986).

In general, there are two things you can control at work; your expertise and your personal relationships. Keeping up with the field by going to workshops, attending lectures, and reading the latest journals will result in greater self-confidence and mastery of theory and skills. Bandura (1977) called this "efficacy expectation," the "conviction that one can successfully execute the behavior required to produce outcomes" (p. 79). You may need to spend your own money to do this, but that shouldn't stop you. In the end, it is your health and your performance, and the price you pay now will be well worth the benefits you get later.

Equally important is to pay attention to building your social network. Good personal relationships, that is, relationships with helpful people and resources, will help you in times of need. Maybe there is a client problem that can best be resolved by talking with another professional in a different location. It will be a lot easier if this professional knew who you were. 
In other words, do everything you can to increase your confidence, your "professional efficacy."

Set realistic goals - Be realistic about what you plan to accomplish. It is very easy to get frustrated by the size of your caseload or not having enough resources to help all your clients. Just as in your personal life, not everything is going to work out the way you hoped, and you are unlikely to be able to do everything you want to do. Work is no different, and you may not have the resources or the authority to do something in a particular situation. Don't plan on being successful in every situation; it will simply lead to emotional exhaustion. The more realistic you are in setting your goals, the more successful you will be.

Diversify -- In the world of stocks and bonds, the message has always been "diversify!" Similarly, research suggests that a varied caseload and a variety of challenges as well as participating in nondirect service activities can help against the negative effects of stress (Acker, 1999; Bell et al., 2003; Proctor \& Steadman, 2003; Rafferty et al., 2001; Skovholt et al., 2001). Engaging in different activities will decrease the fear of dealing with "yet another client", and will help you look forward to do something different. Taking a continuing education course or spending some time talking with a colleague about an article you read can provide some amount of respite from the grind of dealing with one problem client after another. Variety is a good preventive measure to reduce feelings burden.

"Take five" - Take a break, drink some tea, take a walk, that is, take time out from work.

A teacher who tells a student "that's a good question; let me think about it" is buying important time to provide a good answer. A worker may want to leave the office for a few minutes "to pick up some papers" to regain composure during a particularly difficult session. These are good tactics to use so that you can avoid doing something that you might regret later. It is fine to do work on an occasional evening or weekend, but if it is your normal routine, you may want to check your symptom checklist again. Time away from work is there for a reason.

The first defense against burnout is you and you have to take some responsibility you're your personal well-being. The tactics noted above have proven to be helpful for both men and women of all ages. 


\section{Egyptian Journal of Social Work (EJSW) http://ejsw.journals.ekb.eg \\ Print ISSN: 2356-9204 Online ISSN: 2356-9212 Vol 1, Issue 1, June 2015}

While we have focused on the workplace, it is undoubtedly true that other parts of your life may also impact your work and your health. Stress experienced in one area could spill over to other areas one's life. Some of the suggestions above should be helpful no matter what the source of stress. The critical point is not to leave things up to chance, but to take control over the situation to the extent possible.

\section{Organizational Strategies}

The bad news is that research tells us burnout has more to do with the workplace and less to do with person. But, that may also be good news, in that some of the stress-causing aspects of an organization may be changeable. Just as much as individuals need to be aware of their personal well-being, agencies need to be aware of their organizational climate and be receptive to change. Unfortunately, organizations tend not to do anything until there are high levels of absenteeism, high turnover, or poor performance - the organizational equivalent of burnout - before taking the time to examine what is "wrong with the system." Administrators, supervisors, and workers have to take responsibility for changing the system. The best practices we have presented below, we believe can be implemented in budget-constrained environments.

Orientation to the workplace -- the old saying "forewarned is forearmed" is apropos to organizations interested in helping prevent burnout. Orientation means not only providing manuals and handbooks, it also means sharing information on unwritten rules, formal and informal procedures in the organization, who the decision makers are in the organization, and how to access available resources. This type of "mentoring" would reduce trial and error learning by the new worker. This, in fact, is what House (1981) calls information support. A comprehensive and realistic orientation to the agency and the nature of the work will go a long way toward helping the worker by reducing role ambiguity and conflict, and maximizing the potential to work more effectively. If such an orientation does not exist, you should request it and, if necessary, establish procedures to ensure that such an orientation will occur for future hires. This will not only help you, it will also help those who come after you.

Quality of supervision -- there is considerable evidence that the quality of supervision does make a difference to a worker (Azar, 2000; Baruch-Feldman et al., 2002; Gant et al., 1993; Rafferty et al., 2001). 
Supervisors not only have the responsibility to provide direction and feedback, they must also provide support and mentoring. Good supervision will reduce the negative effects of stress and increase better-quality service. However, there is nothing intrinsic or intuitive to good supervisory practices; they require knowledge, skill, and expertise. As such, organizations should provide training and encourage supervisors to attend workshops on management skills.

Continued training and education -- there is considerable evidence supporting the contention that young workers are more atrisk of developing stress symptoms and consequently, feelings of burnout (Barak et al., 2001; Maslach et al., 2001; Song, 2006). Not surprising perhaps, in that younger individuals are more likely to lack confidence because they may have less expertise and mastery over professional tasks compared to their more experienced colleagues. Clearly, it would be in the best interest of the agency to do everything they can to increase worker self-efficacy by providing opportunities for additional training. Confident workers are better able to deal with stress (Schaubroeck \& Merritt, 1997).

Develop support systems - there is substantial evidence to say that social support does make a difference. Finding opportunities during the work day to share concerns, to say thank you, to helping out or clarifying policies and procedures can help reduce stress and strain. It is very important to remember that social support is not simply emotional; it is also practical and informational support. Supervisors and administrators should make a conscious effort to build the community of support within the workplace. It should be part of the work routine.

Safety and comfort -- recent research and public events suggest that the potential for violence from clients may be a nagging concern (Jayaratne, 2004). A quiet place to work and personal safety is something that all agencies should try to provide it's workers.

While individuals can do much to increase their resilience to stress, organizations can do even more to help their workers become even better workers. It is unfair and perhaps even unethical for an agency to not pay attention to the context of work. The idea of "person-in-environment" is a principle we ask social workers to keep in mind their practice. It is perfectly reasonable to expect agency administrators and supervisors to keep this principle in mind as well. 


\section{References}

Acker, G.M. (1999). The impact of clients' mental illness on social workers' job satisfaction and burnout. Health \& Social Work, 24, 112-119.

Adams, R.E., Boscarino, J.A. \& Figley, C.R. (2006). Compassion fatigue and psychological distress among social workers: A validation study. American Journal of Orthopsychiatry, 76, 103-108.

Azar, S.T. (2000). Preventing burnout in professionals and paraprofessionals who work with child abuse and neglect cases: A cognitive behavioral approach to supervision. Psychotherapy in Practice, 56, 643-663.

Bandura, A. (1977). Social learning theory. Englewood Cliffs, NJ: Prentice-Hall.

Barak, M.E., Nissly, J.A., \& Levin, A. (2001). Antecedents to retention and turnover among child welfare, social work, and other human service employees: What can we learn from past research? A review and metanalysis. Social Service Review, 75, 625-661.

Baruch-Feldman, C., Schwartz, J., Brondolo, E., \& Ben-Dayan, D. (2002). Sources of social support and burnout, job satisfaction and productivity. Journal of Occupational Health Psychology, 7, 84-93.

Bell, H., Kulkarni, S., \& Dalton, L. (2003). Organizational prevention of vicarious trauma. Families in Society, 84, 463-471.

Caplan, R.D., Cobb, S. French, J.R.P., Van Harrison, R. \& Pinneau, S.R. (1975). Job Demands and Worker Health. Ann Arbor, MI: Institute for Social Research.

Cropanzano, R., Rupp, D.E., \& Byrne, Z.S. (2003). The relationship of emotional exhaustion to work attitudes, job performance, and organizational citizenship behaviors. Journal of Applied Psychology, 88, 160-169.

Dentsen, I.L. (2002). Re-thinking burnout. Journal of Organizational Behavior, 22, 833-847.

Duffy, M.K. (2002). Social undermining in the workplace. Academy of Management Journal, 45, 331-351.

Ellett, J.E., Ellis, J.I., Westbrook, T.M. \& Dews, D. (2007). A qualitative study of 369 child welfare professionals' 
Egyptian Journal of Social Work (EJSW) http://ejsw.journals.ekb.eg

Print ISSN: 2356-9204 Online ISSN: 2356-9212 Vol 1, Issue 1, June 2015

perspectives about factors contributing to employee retention and turnover. Children and Youth Services Review, 29, 264281.

Freudenberger, H.J. (1980). Burnout: The high cost of achievement. Garden City, NJ: Anchor Press.

Frone, M.R. (2003). Work-family balance. In J.C. Quick \& L.E. Tetrick (Eds.), Handbook of Occupational Health Psychology (pp. 143-162). Washington, DC: American Psychological Association.

Frye, N.K. \& Breaugh, J.A. (2004) Family-friendly policies, supervisor support, work-family conflict, family-work conflict, and satisfaction: A test of a conceptual model. Journal of Business and Psychology, 19, 197-220.

Gant, L.M., Nagda, B.A., Brabson, H.W., \& Jayaratne, S. (1993). Effects of social support and undermining on African American workers' perceptions of coworker and supervisor relationships and psychological well-being. Social Work, 38, 158-164.

Greenglass, E., Fiksenbau, L., \& Burke, R.J. (1996). Components of social support, buffering effects and burnout: Implications for psychological functioning. Anxiety, Stress \& Coping: An International Journal, 9, 185-197.

Guterman, N.B., \& Jayaratne, S. (1994). "Responsibility at risk": Perceptions of stress, control and professional effectiveness in child welfare direct practitioners. Journal of Social Service Research, 20, 99-120.

Hagihara, A., Tarumi, K., \& Miller, A.S. (1998). Social support at work as a buffer of work stress-strain relationship: A signal detection approach. Stress Medicine, 14, 75-81.

Halbesleben, J.R.B. \& Buckley, M.r. (2004). Burnout in organizational life. Journal of Management, 30, 859-879.

Himle, D.P., Jayaratne, S., \& Thyness, P.A. (1989a). The buffering effects of four types of supervisory support on work stress. Administration in Social Work, 13, 19-34.

Himle, D.P., Jayaratne, S., \& Thyness, P.A. (1989b). The effects of emotional support on burnout, work stress and mental health among Norwegian and American social workers. Journal of Social Service Research, 13, 27-45. 
Egyptian Journal of Social Work (EJSW) http://ejsw.journals.ekb.eg

Print ISSN: 2356-9204 Online ISSN: 2356-9212 Vol 1, Issue 1, June 2015

House, J.S. (1981). Work stress and social support. Reading, MA: Addison-Wesley.

Huxley, P., Evans, S., Gately, C., Webber, M., Mears, A. Pajak, S., Kendall, T., Medina, J. \& Katona, C. (2005). Stress and pressures in mental health social work: The worker speaks. British Journal of Social Work, 35, 1063-1079.

Jayaratne, S. (2006). Best practices for avoiding burnout. In C. Franklin, M.B. Harris \& P. Allen-Meares, (Eds.), The School Services Sourcebook. New York, NY: Oxford University Press.

Jayaratne, S., Croxton, T.A. \& Mattison, D. (2004). A national survey of violence in the practice of social work. Families in Society, $85,445-453$.

Jayaratne, S. \& Chess, W.A. (1991). Job satisfaction and burnout: Is there a difference? The Journal of Applied Social Sciences, 15, 245-262.

Jayaratne, S. \& Chess, W.A. (1984). The effects of emotional support on perceived job stress and strain. The Journal of Applied Behavioral Science, 20, 141-153.

Jayaratne, S., Brabson, H.V., Gandt, L.M., Nagda, B.A., Singh, A.K. \& Chess, W.A. (1992). African American practitioners' perceptions of their supervisors: Emotional support, social undermining, and criticism. Administration in Social Work, 16, 27-43.

Lee, R.T., \& Ashforth, B.E. (1996). A meta-analytic examination of the correlates of the three dimensions of job burnout. Journal of Applied Psychology, 81, 123-133.

Leiter, M.P., \& Maslach, C. (2000). Preventing burnout and building engagement: A complete program for organizational renewal. San Francisco: Jossey-Bass.

Leyden-Rubenstein, L.A. (1998). The stress management handbook: Strategies for health and inner peace. New Canaan, CT: NTC Contemporary.

Maslach, C.A. (2003). Job burnout: New directions in research and intervention. Current Directions in Psychological Science, 12, 189-192.

Maslach, C.A. (1982). Burnout: The cost caring. Englewood Cliffs, NJ: Prentice Hall. 


\section{Egyptian Journal of Social Work (EJSW) http://ejsw.journals.ekb.eg \\ Print ISSN: 2356-9204 Online ISSN: 2356-9212 Vol 1, Issue 1, June 2015}

Maslach, C.A., Schaufeli, W.B., \& Leiter, M.P. (2001). Job burnout. Annual Review of Psychology, 52, 397-422.

Maslach, C.A., \& Jackson, S.E. (1986). Maslach burnout inventory manual, (second edition). Palo Alto, CA: Consulting Psychologist Press.

Meltsner, S. (1989). Burnout protection: Survival handbook. King George, VA: American Foster Care Resources.

Mor Barak, M.E., Levin, A. Nissly, J.A. \& Lane, C.J. (2006). Why do they leave? Modeling child welfare workers' turnover intentions. Children and Youth Services Review, 28, 548-577.

Pearlin, L.I., Lieberman, M.A., Menaghan, E.G., \& Mullan, J.T. (1981). The stress process. Journal of Health and Social Behavior, 22, 337-356.

Pearlin, L.I., \& Schooler, C. (1978). The structure of coping. Journal of Health and Social Behavior, 19, 2-21.

Proctor, B.E., \& Steadman, T. (2003). Job satisfaction, burnout, and perceived effectiveness of "in-house" versus traditional school psychologists. Psychology in the Schools, 40, 237-243.

Quinn, R.P. \& Sheppard, L.J. (1974). The 1972-73 Quality of Employment Survey. Ann Arbor, MI: Institute for Social Research.

Quinn, R.P. \& Staines, G. (1978). The 1975-76 Quality of Employment Survey. Ann Arbor, MI: Institute for Social Research.

Pearlin, L.I. and Schooler, C. (1978). The structure of coping. Journal of Health and Social Behavior, 19. 2-21.

Rafferty, Y, Friend, R., \& Landsbergis, P.A. (2001). The association between job skill discretion, decision authority and burnout. Work \& Stress, 15, 73-85.

Raquepaw, J.M., \& Miller, R.S. (1986). Psychological burnout: A componential analysis. Professional Psychology: Research and Practice, 20, 32-36.

Ringstad, R. (2005). Conflict in the workplace: Social workers and victims and perpetrators. Social Work, 50, 305-313.

Schaubroeck, J., \& Merritt, D.E. (1997). Divergent effects of job control on coping

with work stressors: The key role of self-efficacy. Academy of Management Journal, 40, 738-754.

Shirom, A. (2003). Job-related burnout: A review. In J.C. Quick \& 
L.E. Tetrick (Eds.), Handbook of Occupational Health Psychology (pp. 245-264). Washington, DC: American Psychological Association.

Singh, A.K., Jayaratne, S., Siefert, K. \& Chess, W.A. (1995). Emotional support and social undermining as predictors of well-being. The Indian Journal of Social Work, 3, 349-359.

Singh, A.K., Jayaratne, S., Siefert, K. \& Chess, W.A. (1991). Supportive and conflicting social networks and the stressstrain relationship: Moderating effects. Management and Labour Studies, 16, 88-95.

Skovholt, T.M., Grier, T.L., \& Hanson, M.R. (2001). Career counseling for longevity: Self-care and burnout prevention strategies for counselor resilience. Journal of Career Development, 27, 167-176.

Song, K. (2006). Prevalence of client violence toward child and family social workers and its effects on burnout, organizational commitment, and turnover intention: A structural equation modeling approach. Dissertation Abstracts International. The Humanities and Social Sciences, 66, 3465-A.

Tepper, B.J., Duffy, M.K., \& Shaw, J.D. (2001). Personality moderators of the relationship between abusive supervision and subordinates' resistance. Journal of Applied Psychology, 86, 974-983.

Van Dyk, A.C. (2007). Occupational stress experienced by caregivers in the HIV/AIDS field in South Africa. African Journal of AIDS Research, 6, 49-66.

Zapf, D., Seifert, C., Schmutte, B., Mertini, H., \& Holz, M. (2001). Emotion work and job stressors and their effects on burnout. Psychology \& Health, 16, 527-545. 